\title{
Long-Run Elasticities of Electricity Consumption, FDI, Export and GDP in Malaysia
}

\author{
Hussain Ali Bekhet ${ }^{1} \&$ Nor Salwati bt Othman ${ }^{2}$ \\ ${ }^{1}$ Graduate Business School, College of Graduate Studies, Universiti Tenaga Nasional (UNITEN), Malaysia \\ ${ }^{2}$ Department of Finance \& Economics, College of Business and Accounting (COBA), Malaysia \\ Correspondence: Hussain Ali Bekhet, Graduate Business School, College of Graduate Studies, Universiti Tenaga \\ Nasional (UNITEN), 43000 Kajang, Selangor, Malaysia. E-mail: profhussain@uniten.edu.my or \\ drbekhet1953@hotmail.com
}

Received: May 10, 2014

Accepted: May 29, 2014

Online Published: July 25, 2014

doi:10.5539/ijef.v6n8p78

URL: http://dx.doi.org/10.5539/ijef.v6n8p78

\begin{abstract}
This paper examines the co-integration and long run elasticity between electricity consumption (EC) and economic activities (FDI, export and industrial value added) for the 1971-2011 period. The F-Bound test was employed to estimate the long run relationship among the variables and logarithmic multiple regression model to determine the magnitude of changes in electricity consumption when there is a changes in economic activities. It shows a significant long run relationship among electricity consumption, FDI, export and industrial value added. This means that all the aforesaid variables achieve equilibrium in the long run and there is a possibility of causal relationship among variables at least in one direction. Also, it shows an evidence to the future researcher and academician particularly to developed general understanding and guidance for policy formulation.
\end{abstract}

Keywords: long-run elasticities, electricity consumption; export, FDI, industrial value added, Malaysia

\section{Introduction}

As a climate change and greenhouse gas (GHG) emissions become a hot issue in current decade, many researches have an interest to explore the linkages between energy sector and economic performance. The analysis on the linkages between energy and economic performance was started by Kraft and Kraft (1978). They found an evidence of causal relationship running from GNP to energy consumption in USA. Using a different time frame, Akarca and Long (1979) found unidirectional relationship from energy consumption to level of employment. Jumbe (2004); Shui et al. (2004); Mozumder et al. (2007); Tang (2008); Akinlo (2009); Bekhet and Othman (2011b) studies have proven the strong link between energy/electricity and GDP (see Table 1(a)). Furthermore, some studies have been focused on carbon dioxide $\left(\mathrm{CO}_{2}\right)$ emission and GDP (Ang, 2008; Lane, 2011; Saboori, Sulaiman \& Mohd, 2012), while some of them studied the relationship between energy and $\mathrm{CO}_{2}$ emission (Lane, 2011; Pao \& Tsai, 2011; Hussain, Javaid, \& Drake, 2012; Al-Mulali, 2012; Ang, 2007; Bekhet \& Othman, 2013).

In this respect, almost all countries around the globe have their general mission which is sustainable economics growth. As for Malaysia, they faced a great challenged to achieve the GDP growth of 6 percent per year over the next five year as drafted in 10th Malaysia Plan. They have to increase economics activities domestically and internationally by producing a good quality of goods and services, and all this require energy. Unfortunately, energy is one of major source of $\mathrm{CO}_{2}$ emission. It considered to be the biggest culprit behind global warming (Pride \& Baek, 2014; Ivy-Yap \& Bekhet, 2014; Indati \& Bekhet, 2014) and it was created through the combustion of fossil fuels (e.g., coal, gas and oil) to generate electricity. This phenomena would be a big challenge to Malaysia's policy makers in order to achieve prosperity growth while ensuring low energy consumption and $\mathrm{CO}_{2}$ emission. Moreover, Malaysia has agree to reduce the carbon dioxide by up to 40 percent by year 2020 in comparison to 2005 level (Bekhet \& Yasmin, 2013).

On the other hand, economic activities like domestic production, FDI and export also could stimulate growth and reduce the burden of a country from external debt. Thorton (1996); Ahmad and Harnhirun (1995); Awokuse (2007) and Narayan and Smith (2009) found that export could influence economics growth. Besides, Hsioa and Hsioa (2006); Belloumi (2014); Lee and Chang (2009) revealed the existence of relationship between FDI and 
GDP growth (see Table 1(b) and 1(c)). In Malaysia, FDI have been considered as a growth engine to achieve the GDP growth of 6 percent (Bekhet \& Othman, 2013).

In addition to all this, the objectives of this paper are: first, to evaluate the long run relationship between electricity consumption (EC) and innovative economic activities (Industrial value added (VA), foreign direct investment (FDI) and export (X)). They are categoried as innovative economic activities because of the following reasons: (1) In Malaysia, FDI could improve the energy efficiency by restructuring of production and technology transfer (Hamdi et al., 2014). (2) Export could contribute to innovation through technology / productivity effect. The government have spent on research and development, replace the obsolete and dirty technology with new technology to improve environmental quality (Lau et al., 2014) and energy intensity. Thus, quality of human capital and technology could improve and boosted the industrial sector. Second objectives is to measure the degree of elasticity or the magnitude of changes of $\mathrm{EC}$ when the components of economics activities changed (Shahbaz, 2012; Shahbaz \& Lean, 2012). The current study is different with the previous studies in several ways: (a) focus to Malaysia scenario; (b) focus on renewable energy consumption; (c) used industrial value added to represent innovative economic activities rather than common proxy which is GDP. Based on the findings, it would then be possible to determine which policy is the most appropriate for Malaysia scenario. Also, it could serve as evidence to the future researcher and academician particularly to develop general understanding and guidance for policy formulation. The knowledge in this area is crucial in order to develop a solid and effective energy and environment policy.

Table 1a. Previous studies on relationship between electricity and GDP growth

\begin{tabular}{llll}
\hline \multicolumn{1}{c}{ Author (s) } & Countries & \multicolumn{1}{c}{ Variables } & \multicolumn{1}{c}{ Results } \\
\hline \multirow{2}{*}{ Jumbe (2004) } & Malawi & EC & Agriculture: EC $\leftrightarrow$ Y \\
& & GDP $(\mathrm{Y})$ & NonAgriculture: EC $\rightarrow$ Y \\
Shiu et al. (2004) & China & EC & EC $\rightarrow$ Y \\
Mazumder et al. (2007) & Bangladesh & EC per capita & Y $\rightarrow$ EC \\
& Malaysia & EC per capita & \\
Tang (2008) & GDP growth (g) & EC $\leftrightarrow \mathrm{g}$ \\
& Nigeria & EC & EC $\rightarrow \mathrm{g}$ \\
Akinlo (2009) & G & EC $\rightarrow \mathrm{g}$ \\
& Malaysia & EC, G & \\
\hline
\end{tabular}

Table 1b. Previous studies on relationship between export and gdp growth

\begin{tabular}{llll}
\hline \multicolumn{1}{c}{ Author (s) } & Countries & \multicolumn{1}{c}{ Variables } & \multicolumn{1}{c}{ Results } \\
\hline Thornton (1996) & Mexico & Export (X) $\mathrm{g}$ & $\mathrm{X} \rightarrow \mathrm{g}$ \\
Ahmad \& Harnhirun (1995) & Singapore (ASEAN) & $\mathrm{X}, \mathrm{g}$ & $\mathrm{X} \leftrightarrow \mathrm{g}$ \\
Narayan \& Smyth (2009) & Middle East & EC, X, Y & $\mathrm{X} \rightarrow \mathrm{Y}$ \\
& & $\mathrm{G}, \mathrm{X}$ & Bulgaria: X $\leftrightarrow \mathrm{g}$ \\
& Bulgaria; & Import (M) & Czech Republic: X $\rightarrow \mathrm{g}$ \\
Owokuse (2007) & Czech Republic; & Capital (K), & \\
& Poland & Labor (L) & \\
& &
\end{tabular}

Table 1c. Previous studies on relationship between FDI and GDP growth

\begin{tabular}{|c|c|c|c|}
\hline Author (s) & Countries & Variables & Results \\
\hline Hsioa and Hsioa (2006) & East and Southeast Asia & $\begin{array}{l}\text { FDI } \\
X, g\end{array}$ & $\mathrm{FDI} \rightarrow \mathrm{GDP}$ \\
\hline Lee and Chang (2009) & 37 countries in the world & $\begin{array}{l}\text { FDI, Y } \\
\text { Financial development }\end{array}$ & $\begin{array}{l}\text { Long run relationship } \\
\text { between FDI and GDP }\end{array}$ \\
\hline Belloumi (2014) & Tunisia & $\begin{array}{l}\text { FDI } \\
X, g\end{array}$ & $\begin{array}{l}\text { Long run relationship } \\
\text { between FDI and Growth }\end{array}$ \\
\hline
\end{tabular}


The rest of the paper is structured as follows: Section 2 presents the background of electricity consumption and economic activities in Malaysia. Section 3 reviews the past literature. Section 4 defines the variables and data sources, and section 5 describes the methodology of the study. Section 6 includes the results and discussion. Finally, the conclusions and policy implications are presented in section 7.

\section{Electicity Consumption and Economics Activities in Malaysia}

Electricity is one of vital input for many economic activities such as manufacturing, plantation, services, transportation and more. Figure 1, reportes the total electricity consumption in Malaysia growth by 6.6 percent for the 1971-2011 period. The industrial sectors lead as a major consumer of electricity with its share accounted about 43.9 percent of total consumption in 2011. It followed by commercial, residential, agriculture and transportation sectors which accounted 34.3 percent, 21.4 percent, 0.3 percent and 0.2 percent of total consumption, respectively (National Energy Balance, 2011).

While, the export and FDI supported the development of commercial, residential, agriculture and transport sectors as well as contributed to the growth of electricity usage. Malaysian export and FDI show an increasing trend and growth rate by 6.8 percent and 8.8 percent, respectively for the above period (see Figure 1). In short, electricity consumption, GDP, FDI and X show an upward trend hand in hand. Since then, there is a possibility of a long run interaction among these economic indicators.

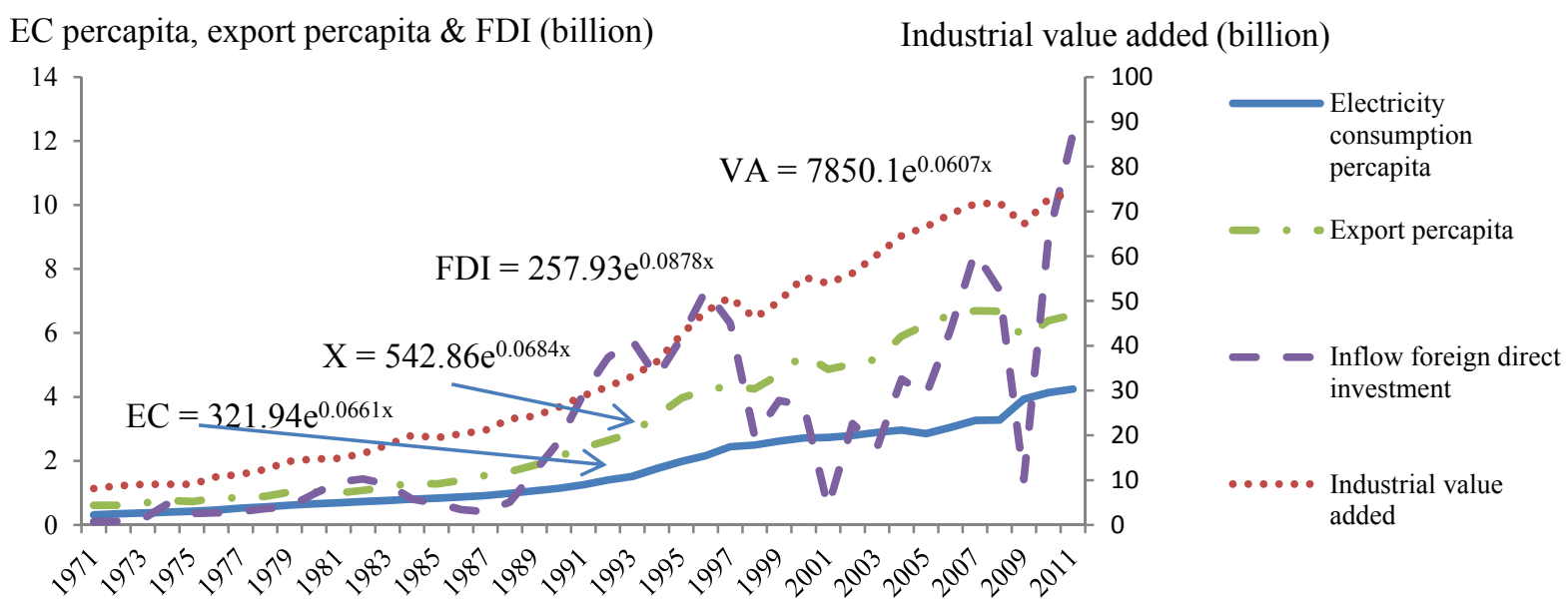

Figure 1. Time trend of the variables for the 1971-2011 period

The main contribution of the export growth rate for the 1971-2011 period was the sales of the manufacturing goods such as electrical and electronic products. Thee ASEAN countries, followed by Japan, China, European Union and United State are the main Malaysian export partners. The export is very important weapon for a country to stimulate growth and to reduce the long term debt. Also, FDI also showed an increasing trend for the above period. Recently, Minister of International Trade and Industry (MITI) announced that Malaysia's FDI increased by 24 percent as compared to 2012. Manufacturing, services and mining sectors contributed to this performance by 37.6 percent, 28.8 percent and 28.7 percent, respectively.

VA, FDI and X are considered as an innovative economic activities due to its ability to absorb knowledge and technical knowhow from their business partners. These activites are linked to electricity consumption in two different axes (see Figure 2). Scale effect: The increased in FDI and X will lead to a substantial increase in the scale of production and consumption of electricity.Technology effect:The increased in FDI and X lead to increase the scale of production, but reduce the electricity consumption through its ability to absorb new technology from their partners. They used the energy saving and new clean machineries; and removed the obsolete and dirty machineries. 


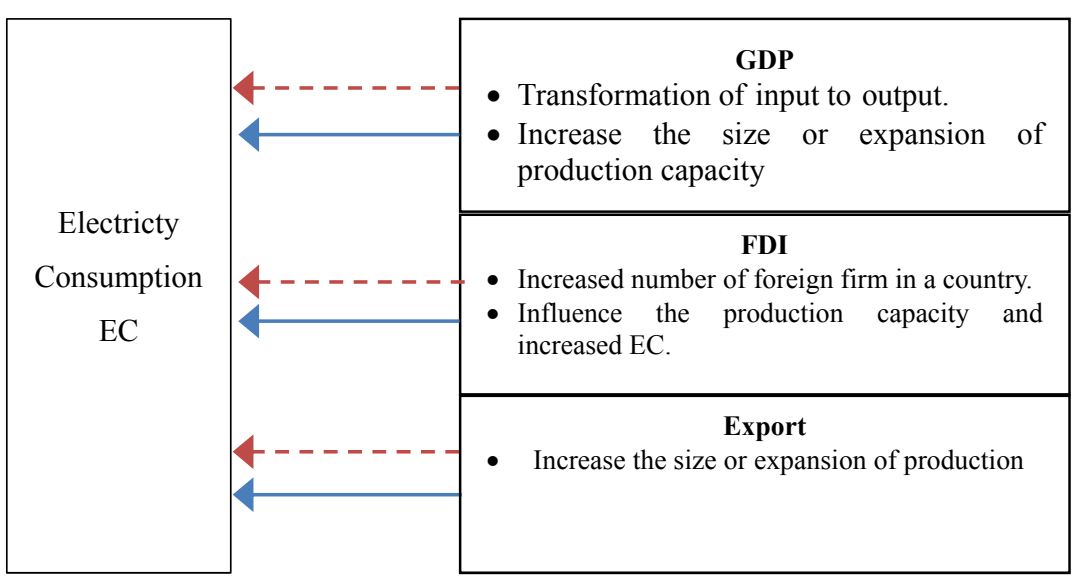

Figure 2. The link between economic activities and electricity consumption

Note. $\longleftarrow$ referes to scale effect and $\longleftarrow-$ refers to Technique/productivity Effect.

\section{Past Studies}

The current study investigates the roles of innovative economic activities in determining the level of electricity or energy consumption in Malaysia. Industrial value added, FDI and export are employed to represent innovative economic activities due to its ability to absorb knowledge and technologies knowhow from other countries and then translate it into production efficiency that increased output by reduce the electricity consumption.

The past literature review are split into three strands. The first strand deals with the link between EC, export and GDP. Awokuse (2007) examined the causal relationship between export, imports and economic growth by using Johansen co-integration and granger causality test for transition economies (Bulgaria, Czech Republic and Poland). The author found all variables in his study are co-integrated for 1994-2004 period. Also, he found bidirectional granger causality between X and GDP growth; and unidirectional causality running from GDP growth to import in the short run. Narayan and Smyth (2009) examined the long run and the causal relationship among EC, GDP and X in six countries (Iran, Israel, Kuwait, Oman, Saudi Arabia and Syria) for 1974-2002 period. Westerlund (2006) Utilized panel co-integration and FMOL model. The results shown that the co-integration relationship among GDP, EC and export is exited. Furthermore, the short run causality running from EC to GDP, GDP to export and no direct causal relationship between EC and export have found. In the long run, they confirmed the bidirectional causality from export to GDP and EC.

Lean and Smyth (2010a) utilized annual time series (capital, labor, EC and X) for 1971-2006 period. They revealed the bidirectional short run and long run causality between EC and GDP, and unidirectional long run causality from X and GDP, however no connection between X and EC. In another paper, Lean and Smyth (2010b) analyzed the co-integration and causal relationship using the same methodology to Malaysia time series over the 1970-2008 period. Instead of using EC, they employed electricity generation (EG) to represent energy and combined it with X, price and GDP. They found the existence of co-integration relationship among the aforesaid variables, and long run causal relationship from GDP and price to EG, and EG to X.

Halicioglu (2011) used bound testing procedure and granger causality to analyze a dynamic relationship between income, EC and $\mathrm{X}$ in Turkey. He revealed the causal relationship running from $\mathrm{X}$ and $\mathrm{EC}$ to output in the long run. While in the short run there is a bidirectional causality between EC and output; and X and output. Also, there is unidirectional causality running from X to EC. Sami (2011) used the same methodology to analyze co-integration and causal relationship between X, EC and income per capita in Japan for 1960-2007 period. The results show a long run causality running from $\mathrm{X}$ to $\mathrm{EC}$; and income per capita to $\mathrm{EC}$.

Sadorsky (2011) analyzed the dynamic relationship between X and EC in the Middle East countries and found bidirectional causality between import and EC. He also found a unidirectional causality running from $\mathrm{EC}$ to $\mathrm{X}$. In another study, Sadorsky (2012) analyzed a dynamic relationship between EC, output and X in South America. He found unidirectional causality running from EC to X and import. Dedeoglu and Kaya (2013) also analyzed a co-integration and causal relationship between EC, GDP and trade (export minus import) using panel co-integration method developed by Canning and Pedroni (2008). The results shows the existence of co-integration relationship among variables and bidirectional causal relationship from EC and trade. 
The second strand deals with the relationship between energy, FDI and GDP. Bekhet and Othman (2010) examined the causal relationship between EC, CPI, GDP and FDI in Malaysia for the 1971-2009 period. They found the existence of the long run relationship among variables and the causal relationship between EC and FDI Utilizing panel Generalized Method of Moments regression, Sadorsky (2010) examined the relationship between EC, income, price and FDI to emerging economies such as Argentina, Brazil, Russia, India, and China (BRIC) for 1990-2006 period. The result shows a positive relationship between FDI and EC in emerging countries. This indicated that due to scale effect the increased in FDI could increased energy usage. Pao and Tsai (2010) used panel co-integration test and VECM to examine the co-integration and causal relationship among $\mathrm{EC}, \mathrm{CO}_{2}$, FDI and GDP in BRIC countries.The results show a co-integration relationship among variables and bidirectional causality between EC and FDI in the short run and unidirectional causality from FDI to EC in the long run. Sbia, et al. (2014) analyzed the long run relationship among energy consumption, FDI, trade openness, $\mathrm{CO}_{2}$, emissions, GDP and green energy in United Arab Emiriate for the 1975-2011 period. They revealed the existence of long run relationship among variables with structural break. While, Hamdi, et al. (2014) explored the relationship between electricity consumption, FDI, capital, labor and economic growth for Kingdome of Bahrin for the 19802010 period. They found the existence of long run relationship with trend among the variables.

The third strand is regarding elasticity of electricity consumption. Huang (1993) examined the electricity-GDP growth for China for the 1950-1980 period. Keeping other thing remained constant, he found $1 \%$ increased in GDP caused the electricity changed by more than 1\%. In the case of Taiwan for the 1955-1996 period, Holtedahl and Joutz (2004) revealed income elasticity of electricity demand is equal to 1 in the long run.This indicated that $1 \%$ increased in income caused the electricity to increased by $13 \%$. Silk and Joutz (1997) investigated the short run and long run elasticity of electricity demand where the short run and long run income elasticity is 0.01 and 0.15 to 0.28 , respectively. Based on previous literature, we conclude that length of time (short run and long run) and the type of countries (developed or developing countries) contribute to different degree of elasticity.

Based on the previous findings, this study hypothesized that there is a long run relationship between export, FDI and electricity consumption in Malaysia. In particular, the positive relationship will exist between EC and innovative economic activities if the scale effect exceed the technical effect. However, if the technical effect is greater than scale effect, the relationship between them could be negative.

\section{Data and Variables}

In current paper, annual time series data of EC, X, FDI inflow (FDI), and VA for the 1971-2011 period for Malaysia are used. Since the amount of electricity consumption and export is huge compare to other time series data, we used electricity consumption percapita (EC devide total population) and export percapita (export divide total population) as a proxy to measure level of electricity usage and export activity in Malaysia. The reason of utilizing the small value of respective time series data is to induce the process to achieve stationarity.

FDI, $\mathrm{X}$ and VA are used to represent the innovative economics activities due to its' capability to absorb new technology from other countries through knowledge and labor transfer. For instant, through FDI, the host country could built up or improve human capital and infrastructures (Balasubramanyam et al., 1999), increase return in domestic production (Luiz, 1997), and increase their capability of advance technology (Borensztein et al., 1998). Battern and Vo (2009) stated that FDI can stimulate economic growth through technology transfer and diffusion, spillover effects and productivity gains and introduction of new process and managerial skills.

All variables are expressed in logarithmic form in order to obtain more stationary behavior (Bekhet \& Othman, 2010), and reduce the possibility of heteroscadasticity and autocorrelation to be exist. The detail and sources of variables used in this study are shown in table 2 .

Table 2. Variables details $(2005=100$, as base year $)$

\begin{tabular}{|c|c|c|c|}
\hline Variables & Units & Source & Purposes \\
\hline $\begin{array}{l}\text { Electricity consumption percapita } \\
\text { (EC) }\end{array}$ & Million kWh & World Bank & To measure the degree of electricity usage. \\
\hline Industrial value added (VA) & Million USD (constant price) & World Bank & To measure the economic acitivities with innovation \\
\hline FDI inflow (FDI) & Million USD (constant price) & UNCTAD & To measure the economic acitivities with innovation \\
\hline Export percapita (X) & Million USD (constant price) & World Bank & To measure the economic acitivities with innovation \\
\hline
\end{tabular}

One of the significant step in this area is to improve data quality. This is because it would reduce the possibilities of specification bias to be occurred. In one hand, the normality test of the data and degree of correlation among 
data employed in this study are observed. Normality mean symmetric or skewness and has a bell shape with a peakedness and tail thickness (Hill et al., 2008). For hypothesis testing of normality, we used Jarque-Bera (J-B) normality test. The p-value for J-B is greater than 5 percent indicate that we failed to reject $H_{0}$ or the data is normally distributed and vice versa.

Table 3 shows the results of the descriptive statistic and interrelationship among the variables of the study. The result of the J-B test (P-value $>0.05)$ indicates that most of the variables are almost normally distributed.

Table 3. Descriptive Statistic and correlation matrix of the variables

\begin{tabular}{lcccc}
\hline & LEC & LFDI & LVA & LX \\
\hline Mean & 7.162 & 7.397 & 10.243 & 7.732 \\
Median & 7.134 & 7.418 & 10.270 & 7.787 \\
Maximum & 8.354 & 9.411 & 11.216 & 8.808 \\
Minimum & 5.736 & 4.592 & 9.001 & 6.414 \\
Std. Dev. & 0.798 & 1.274 & 0.734 & 0.831 \\
Skewness & -0.158 & -0.377 & -0.205 & -0.115 \\
Kurtosis & 1.695 & 2.149 & 1.664 & 1.477 \\
Jarque-Bera & 3.081 & 2.210 & 3.336 & 4.051 \\
Probability & 0.214 & 0.331 & 0.189 & 0.132 \\
Observations & 41 & 41 & 41 & 41 \\
LEC & 1 & & & \\
LFDI & 0.842 & 1 & & \\
LVA & 0.895 & 0.844 & 1 & \\
LX & 0.892 & 0.848 & 0.895 & \\
\hline
\end{tabular}

Source: Output of Eviews package, Version 8.

Beside the relationship among variables, partial correlation matrix is used. The correlation coefficient between $\mathrm{EC}$ and FDI, $\mathrm{X}$ and VA are positive and strong relationship. This means if economic activities increased, electricity consumption also will be increased, vice versa.

\section{Methodology}

The main objective of the present paper is to investigate the long-run relationships between electricity consumption (EC) and the degree of economic activitites, and estimating the electricity consumption elasticities over the period 1971-2011. By taking Keynesian theory of aggregate demand (AD) as the underpin theory, the level of electricity demand and consumption is depend on output produce (VA is used as a proxy), FDI and X. Also, FDI and X would stimulate VA through scale effect and influence the level of electricity demand in the country. Following the empirical literature in EC, it is plausible to form the long-run relationship among EC, FDI, $\mathrm{X}$, and GDP in linear form, with a view of testing stantionarity, the long-run and estimating the electricity consumption elasticities between these variables in Malaysia as follows .

$$
l e c_{t}=\beta_{0}+\beta_{1} l v a_{t}+\beta_{2} l f d_{t}+\beta_{3} l x_{t}+\varepsilon_{t}
$$

where, $l e c_{t}, l v a_{t}, l f d_{t}$, and $l x_{t}$ represent logarithm of electricity consumption percapita, industrial value added, FDI and export percapita, respectively. The stationary test is a crucial step to ensure the quality of data that is used to analyse the co-integration among the above variables. Macroeconomic time series is usually non stationary and posses a trend over time. Evidence from the past studies suggested the presence of unit root in most of financial and economics variables (Montgomery et al., 2008; Bekhet \& Mugableh, 2012). Stationary is a condition when the time series has constant mean, constant variance and constant auto covariance structure. There are number of methods to test the stationarity. Traditionally, stationarity test such as ADF test (Dickey \& Fuller, 1979), P-P test (Phillip \& Perron, 1988), KPSS (Kwiatkawski, Phillip, Schmidt, \& Shin, 1992), DF-GLS (Elliot, Rothemberg, \& Stock, 1996) and Ng Perron (Ng \& Perron, 2001). In this study we applied ADF, PP and KPSS tests and the results are compared among each others for consistency purposes and robostness. Theoritically, all of the aforesaid tests could solve an autocorrelation and heteroscadasticity problems in the residual of OLS regression. $\mathrm{ADF}$ test can overcome this problem by adding lagged value $(k)$ of dependent variable and the appropriate number of lag is depend on minimum value of SIC and AIC of OLS regression. ADF test followed the model in equation 2. 


$$
\Delta Y_{t}=\delta Y_{t-1}+\sum_{i=1}^{k} \alpha_{i} \Delta Y_{t-1}+v_{t}
$$

On the other hand, PP test overcome an autocorrelation problem by modifying the test statistic. The hypothesis stated, $H_{0}: \delta=0$ or non stationary and $H_{1}: \delta<0$ for stationary. However, as for KPSS statistic, the hypothesis was in opposite manner. If ADF statistic (PP statistic) is greater than the critical value of $5 \%$, then $H_{0}$ cannot be rejected, suggesting that the time series is not stationary. However, if the time series is not stationary, we should proceed with stationary test at first difference I(1), then if time series still not stationary, we proceed with stationary test at second difference I(2). Usually, the macroeconomic data are stationary at first and second difference (Bekhet \& Othman, 2011).

Co-integration test.

After stationary test have been done, we proceed with co-integration test. The purpose of this aforesaid test is to determine the existence of the long run relationship among time series. For the purpose of this study, we employed ARDL bound testing approach proposed by Pesaran, Shin and Smith (2001). There are 3 advantages of this method. First, it is appropriate for small sample size. Second, it also appropriate if time series are stationary at I(0) or I(1) or mixed. And finally, ARDL can be used to estimate short run and long run relationship simultaneously. The ARDL bound test is based on the unrestricted error correction model (UECM) as shows in equation (3).

$$
\begin{gathered}
\Delta l e c_{t}=\alpha+\theta_{1} l e c_{t-1}+\theta_{2} l f d_{t-1}+\theta_{3} l x_{t-1}+\theta_{4} l v a_{t-1}+\sum_{i=1}^{k} \beta_{1} \Delta l e c_{t-i}+\sum_{i=0}^{l} \beta_{2} \Delta l f d_{t-i}+ \\
\sum_{i=0}^{m} \beta_{3} \Delta l x_{t-i}+\sum_{i=0}^{n} \beta_{4} \Delta l v a_{t-i}+\varepsilon_{t}
\end{gathered}
$$

Where $\Delta$ is the first difference operator, lec, lfd, $l x$ and $l v a$ represent logarithmic of electricity consumption, FDI, export and industrial value added respectively. For the purposed of this study, the structural lags are restricted to 2 because of we are using a small sample size and more lags could reduce the degree of freedom in the analysis. Alternatively, the selection of lag is depend on the minimum value of AIC and SBC. Then, Breush-Godfrey serial correlation Lagrange Multiplier test was used to detect the serial correlation problem. We set $H_{0}$ : No serial correlation versus $H_{1}$ : Serial correlation exist. If the p-value is greater than $5 \%$ level of significance, we cannot reject $H_{0}$ for no serial correlation to be exist.

To determine long run relationship among the variables, we set $H_{0}: \theta_{1}=\theta_{2}=\theta_{3}=\theta_{4}=0$ for no co-integration versus $H_{1}: \theta_{1} \neq \theta_{2} \neq \theta_{3} \neq \theta_{4} \neq 0$ for co-integration exist. The decision to reject/accept $H_{0}$ is depended on the value of F-statistic. In this case, we are using critical bound generated by Narayan (2005) due to it's ability to cater small sample size $(30<\mathrm{t}<80)$, while critical bound generated by Pesaran et al $(2001)$ are suitable for large sample size $(500<\mathrm{t}<40,000)$. The F-statistic value is compare to the $\mathrm{I}(1)$ and $\mathrm{I}(0)$ value provided by Narayan (2005). If the F-statistic is greater than respective I(1) value, $H_{0}$ will be rejected. Conversely, if F-statistic value is below $\mathrm{I}(0)$, we failed to reject $H_{0}$, which means not co-integrated. In addition to that, CUSUM test is applied to assess the stability of ARDL model. If the plot of CUSUM and CUSUMQ statistics stay within the 5 percent range of the significance level (within the two straight lines), the null hypothesis states that all coefficients in the model are stable and cannot be rejected (Bahmani-Oskooee \& Ng, 2002; Bekhet \& Matar, 2013).

In order to realize the second objective of this study which is to assess electricity elasticity, the following equation is computed (Shahbaz, 2012; Shahbaz \& Lean, 2012).

$$
l e c_{t}=\gamma_{0}+\gamma_{1} l f d_{t}+\gamma_{2} l x_{t}+\gamma_{3} l v a_{t}+v_{t}
$$

where; $\gamma_{0}=\frac{\boldsymbol{\alpha}}{\boldsymbol{\theta}_{\mathbf{1}}} ; \gamma_{1}=\frac{-\boldsymbol{\theta}_{\mathbf{2}}}{\boldsymbol{\theta}_{\mathbf{1}}} ; \gamma_{2}=\frac{-\boldsymbol{\theta}_{3}}{\boldsymbol{\theta}_{\mathbf{1}}}$ and $\gamma_{3}=\frac{-\boldsymbol{\theta}_{\mathbf{4}}}{\boldsymbol{\theta}_{\mathbf{1}}}$; The value of $\alpha$ and $\theta_{1}-\theta_{4}$ are taken from equation 3 . The expected sign of $\gamma_{i}$ and $\gamma_{2}$ is $<0$ if FDI and X adopts energy efficiency technology, otherwise $\gamma_{1}$ and $\gamma_{2}$ is $>0$, indicate the positive relationship between EC and FDI and X; and Malaysia not yet able to implement energy efficiency technology. $\gamma_{3}<0$ indicates that electricity as a giffen good and $\gamma_{3}>0$ indicates that scale effect induce the consumption of electricity. Alternatively, if the model in equation 3 is insignificant, we will use double $\log$ model to measure electricity elasticity (see equation 1 ).

\section{Result and Discussion}

Table 4 shows that all the variables of the study are stationary at I(1). However, some variables showed a stationary 
behavior at level and with trend when ADF and KPSS tests are applied. These are $l e c$ and $l f d$, while the remainders time series data performed stationary at level when we applied KPSS test.

Table 4. The results of the unit root test

\begin{tabular}{|c|c|c|c|c|c|c|c|}
\hline \multicolumn{2}{|c|}{ Variables } & \multicolumn{2}{|c|}{$\mathrm{ADF}$} & \multicolumn{2}{|c|}{ P.P } & \multicolumn{2}{|c|}{ KPSS } \\
\hline vart & & $\mathrm{I}(0)$ & $\mathrm{I}(1)$ & $\mathrm{I}(0)$ & $\mathrm{I}(1)$ & $\mathrm{I}(0)$ & $\mathrm{I}(1)$ \\
\hline \multirow{2}{*}{ lec } & No trend & -1.092 & $-3.740 *$ & -1.399 & $-5.165^{*}$ & 0.792 & $0.185^{*}$ \\
\hline & @ trend & $-4.457^{*}$ & $-3.892 * *$ & -1.610 & $-5.293 *$ & $0.111^{*}$ & $0.065^{*}$ \\
\hline \multirow{2}{*}{ lfd } & No trend & -2.192 & $-8.199 *$ & -2.192 & $-8.339 *$ & $0.699 *$ & $0.082 *$ \\
\hline & @ trend & $-3.552 * *$ & $-8.122 *$ & $-3.503 * * *$ & -8.274 & $0.699 *$ & $0.082 *$ \\
\hline \multirow{2}{*}{ lva } & No trend & -1.475 & $-5.806 *$ & -1.634 & $-5.791 *$ & 0.781 & $0.285^{*}$ \\
\hline & @ trend & -0.807 & $-5.994 *$ & -0.760 & $-6.106^{*}$ & $0.172 *$ & $0.127^{*}$ \\
\hline \multirow{2}{*}{$l x$} & No trend & -1.148 & $-5.922 *$ & -1.155 & $-5.925^{*}$ & 0.775 & $0.258 *$ \\
\hline & (a) trend & -0.658 & $-6.117 *$ & -0.712 & $-6.118^{*}$ & $0.122 *$ & $0.162 *$ \\
\hline
\end{tabular}

Note. $* * *$ and $* * *$ indicate significant at $1 \%, 5 \%$ and $10 \%$ respectively.

Source: Output of Eviews package, Version 8.

Selection of the approptiate lag length is necessary for the F-bound approach because the calculation of F statistic is sensitive to any lag order (Shahbaz, 2012). Based on the minimum value of SIC and AIC, the appropriate lag length for this model is 2 . Then Hendry's general-to-specific method is used by eliminate the highest insignificant short run independent variables until the model is free from serial correlation problem.

Then, F-bound test is used to assess the long run relationship. The results shows that the F-statistic value is greater than upper bound critical value (see table 5). This indicate that all variables are co-integrated and moving together in the long run. These results are confirmed when used the Engle-Granger co-integration procedure at 1\% significant level. This is consistent with earlier studies (Halicioglu, 2011; Awokuse, 2007; Lean \& Smyth, 2010a, 2010b; Dedeoglu \& Kaya, 2013). This result shows that all of the aforesaid variables are linked together and influence each other in the long run. Also, it indicates that there is a possibility of a causal relationship to be exist at least in one direction.

Table 5. F-bound test result

\begin{tabular}{|c|c|c|c|c|c|}
\hline \multirow{2}{*}{ Model } & \multirow{2}{*}{ F-statistics } & \multirow{2}{*}{ Significance Level } & \multicolumn{2}{|c|}{ Critical value } & \multirow{2}{*}{ Decision } \\
\hline & & & $\mathrm{I}(0)$ & $\mathrm{I}(1)$ & \\
\hline \multirow{3}{*}{$\mathrm{f}(E C \mid V A, X, F D I)$} & & $1 \%$ & 4.59 & 6.37 & \\
\hline & $7.491^{*}$ & $5 \%$ & 3.28 & 4.63 & Co-integrated \\
\hline & & $10 \%$ & 2.70 & 3.90 & \\
\hline
\end{tabular}

Note. The critical values are taken from Narayan (2005). * denote statistically significant at $1 \%$ level.

The long-run and short-run dynamic results are reported in Table 6. The diagnostic tests for the model are as presented at the bottom of the table.

Table 6. The unrestricted error-correction model results

\begin{tabular}{lllll}
\hline Variables & Coeficient & Std Error & t-stat & Prob \\
\hline $\operatorname{lec}(-1)$ & -0.236 & 0.071 & -3.320 & 0.002 \\
$\operatorname{lfd}(-1)$ & 0.023 & 0.012 & 1.915 & 0.065 \\
$\operatorname{lva}(-1)$ & 0.052 & 0.020 & 2.633 & 0.013 \\
$\operatorname{lx}(-1)$ & 0.136 & 0.070 & 1.955 & 0.059 \\
$c$ & & & & \\
$\Delta l e c(-2)$ & 0.299 & 0.161 & 1.860 & 0.072 \\
$\Delta l f d(-1)$ & -0.026 & 0.011 & -2.417 & 0.022 \\
$\Delta l v a(-2)$ & -0.227 & 0.123 & -1.838 & 0.076 \\
\hline
\end{tabular}

Note. $\mathrm{R}^{2}=0.38$; Adj $\mathrm{R}^{2}=0.26$; Durbin Watson= 2.06; and prob. Chi square $=0.7883$. Source: Output of the Eviews package, Version 8 . 
In addition to that, the CUSUM test was applied to assess the stability of long run parameters for electricity consumption model. The plotted data is found within the critical bounds, implying that all coefficents in the error correction model are stable (see Figure 3). Therefore, we can use this model for decision making purposes which involving long run relationship among EC, FDI, X and VA variables since the parameter in this model follow a stable pattern during estimation period.

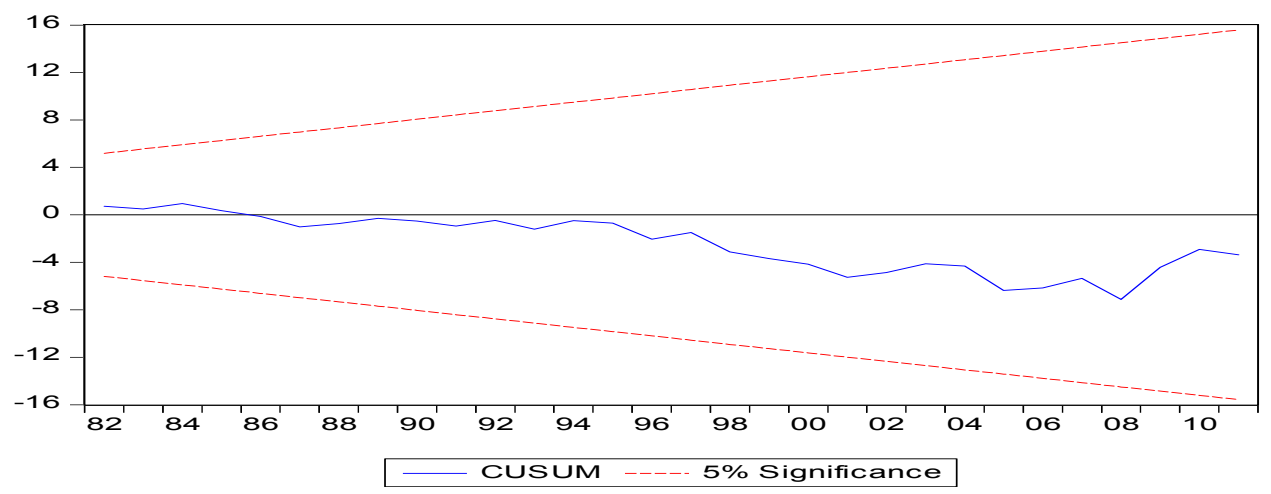

Figure 3. Stability test

Since long run relationship exists among the variables without serial correlation problem and the UECM is stable, the logarithmic multiple regression model (Equation 4) is used to assess the long run elasticity of electricity consumption. The findings are shown in Equations (5).

$$
l e c_{t}=0.083 l f d_{t}+0.480 l x_{t}+0.354 l v a_{t}+\mu_{t}
$$

Assuming other thing remained constant, the results reveale a 100 percent increase in the FDI, export and industrial value added will contribute to $8.3,48$, and 35.4 perecnt, respectively increased in electricity consumption. For instant, export are found as a major influencer of electricity usage compare to FDI and industrial value added in the long run. Besides, the parameters of the variables (Equation 5) indicate that the scale effect was exceed the performance of technology/productivity effect during the period of study (19712011).

\section{Conclusions and Policy Implications}

This study examines the long run relationship between electricity consumption and economic activities in Malaysia for the 1971-2011 period. Also, it assesed the long run elasticities of electricity consumption. Annual time series for the industrial value added, FDI and export are used to represent innovative economic activities due to its' ability to absorb new technology from other countries through knowledge, labor transfer and then, through scale effect its' stimulate economic growth.

ADF, PP and KPSS tests showed that the data is stationary at I(1) which mean the data is moving around mean and have constant variance. These tests also able to tackle the problem of autocorrelation if it exists. Then, F-bound test is applied to assess the long run relationship among aforesaid variables. The results shown that the F statistic fell beyond the upper bound critical value provided by Narayan (2005), and this indicated the existence of the long run relationship among the variables. This result is confirmed by using Engle and Granger co-integration procedure.Also, it is consistent with Halicioglu (2011); Awokuse (2007); Lean and Smyth (2010a, 2010b); Dedeoglu and Kaya (2013). Besides, it gives us an information that all the aforesaid variables will achieve equilibrium in the long run and there is a possibility of causal relationship among variables at least in one direction. In addition to that, the logarithmic multiple regression model is employed to determine the magnitude of changes in electricity consumption when there is a change in economic activities. The results revealed that export as a major determinant of electricity consumption compare to FDI and industrial value added in the long-run. Therefor, the results indicate that a 100 percent increased in export, contribute to 48 percent increased in electricity consumption. Moreover, the empirical evidence showed that there is a positive relationship between EC with VA, FDI and X.

Validating the positive relationship between EC and innovative economic activity's components (VA, FDI and X) in Malaysia is crucial for designing energy efficiency policy. However, in order to realize the Malaysia aspiration in year 2020, all the authority of a country has to work hand in hand seriously. Also, it is recommended that the 
policy maker has to encourage FDI and export activities because through them we can stimulate economic growth and learn production techniques that can enhance energy efficiency from more advanced economies and then, replace the obsolete technologies to green technologies.

Also, the policy makers (e.g., SEDA, KETTHA, TNB) have to ensure that Malaysia has an adequate electrical power because any shortage of electricity could spoil the economic activities and reflex a bad reputation of a country. Therefore, they should seriously look into this matter and find the other sources of electricity power, such as wind power, bio-gas and solar.

\section{References}

Ahmad, J., \& Harnhirun, S. (1995). Unit Roots and Co-integration in Estimating Causality Between Export and Economic Growth: Empirical Evidence From the ASEAN countries. Economics Letter, 49, 329-334. http://dx.doi.org/10.1016/0165-1765(95)00678-9

Akarka, A. T., \& Long, T. (1979). On the relationship between energy consumption and GNP: A re-examination. Journal of Energy Development, 5, 326-331.

Akinlo, A. E. (2009). Electricity consumption and economic growth in Negeria: Evidence from cointegration and co-feature analysis. Journal of Policy Modeling, 31, 681-693. http://dx.doi.org/10.1016/j.jpolmod.2009.03.004

Al-Mulali, U. (2012). Factors Affecting CO2 Emission in The Middle East: A Panel Data Analysis. Journal of Energy, 44, 564-569. http://dx.doi.org/10.1016/j.energy.2012.05.045

Ang, J. B. (2007). CO2 Emissions, Energy Consumption And Output In France. Energy Policy, 1(35), 47724778. http://dx.doi.org/10.1016/j.enpol.2007.03.032

Ang, J. B. (2008). Economic Development, Pollutant Emissions And Energy Consumption In Malaysia. Journal of Policy Modeling, 30, 271-278. http://dx.doi.org/10.1016/j.jpolmod.2007.04.010

Asafu-Adjaye, J. (2000). The relationship between elasticity consumption, electricity prices and economics growth: Time series evidence from Asian developing countries. Energy Economics, 22, 615-625. http://dx.doi.org/10.1016/S0140-9883(00)00050-5

Baek, J., \& Pride, D. (2014). On the Income-Nuklear Energy-CO2 Emissions nexus revisited. Energy Economics, 43, 6-12. http://dx.doi.org/10.1016/j.eneco.2014.01.015

Bahmani-Oskooee, N. W. (2012). Long run Demand for Money in Hong Kong: An Application of the ARDL Model. International Journal of Business and Economics, 1(2), 147-155.

Balasubramanyam, V. N., Salisu, M., \& Sapsford, D. (1999). Foreign Direct Investment as an Engine Of Growth. Journal of International Trade and Economic Development: An International and Comparative, 8(1), 2740. http://dx.doi:10.1080/09638199900000003

Bekhet, H. A., \& Matar, A. (2013). Co-integration and Causality Analysis Between Stock Prices and Their $\begin{array}{lllll}\text { Determinates in Jordan. Economic } & \text { Modelling, }\end{array}$ http://dx.doi.org/10.1016/j.econmod.2013.07.012

Bekhet, H. A., \& Mugableh, M. I. (2012). Investigating Equilibrium Relationship Between Macroeconomics Variables and Malaysian Stock market Index Through Bound Test Approach. International Journal of Economics and Finance, 4, 69-81. http://dx.doi.org/10.5539/ijef.v4n10p69

Bekhet, H. A., \& Othman, N. S. (2010). Analyzing the elasticities of electricity price for rural and urban area in Malaysia: Non-linear approach. ICOSCD2010, Proceeding, UPM, Malaysia.

Bekhet, H. A., \& Othman, N. S. (2011a). Assessing the Elasticities of Electricity Consumption for rural and urban areas in Malaysia: A Non-linear approach. International Journal of Economics and Finance, 3(1). http://dx.doi.org/10.5539/ijef.v3n1p208

Bekhet, H. A., \& Othman, N. S. (2011b). Causality Analysis Among Electricity Consumption, Consumer expenditure, GDP and FDI: Case Study of Malaysia. Journal of Economics and International Finance, 3(4), $228-235$.

Bekhet, H. A., \& Othman, N. S. (2013). Co-Integration Analysis among FDI, Energy Consumption and Carbon Dioxide Emission in Malaysia. 2nd International Economics Business Management Conference. IEBMC2013, Malaysia.

Bekhet, H. A., \& Yasmin, T. (2013). Disclosing the Relationship among CO2 Emissions, Energy Consumption, 
Economic Growth and Bilateral Trade between Singapore and Malaysia: An Econometric Analysis. International Journal of Social, Human Science and Engineering, 7(9), 50-55.

Belloumi, M. (2014). The Relationship Between Trade, FDI and Economics Growth in Tunisia: An Application of the Autoregressive Distributed Lag Model. Economic system. http://dx.doi.org/10.1016/j.ecosys.2013.09.002

Borensztein, E., Gregorio, J. D., \& Lee, J. W. (1998). How Does Foreign Direct Investment Affect Economic Growth? Journal of International Economics, 45, 115-135. http://dx.doi.org/10.1016/S0022-1996(97)00033-0

Canning, D., \& Pedroni, P. (2008). Infrastructure, long-run economic growth and causality tests for cointegrated panels. The Manchester School, 76(5), 504-527. http://dx.doi.org/10.1111/j.1467-9957.2008.01073.x

Dedeoglu, D., \& Kaya, H. (2013). Energy Use, Exports, Imports and GDP: New Evidence from the OECD Countries. Energy Policy, 57, 469-476. http://dx.doi.org/10.1016/j.enpol.2013.02.016

Dickey, D., \& Fuller, W. A. (1979). Distribution of the Estimates for Autoregressive Time Series with Unit Root. Journal of The American Statistical Association, 75, 427-431. http://dx.doi:10.1080/01621459.1979.10482531

Elliott, G., Rothenberg, T. J., \& Stock, J. H. (1996). Efficient Tests for an Autoregressive Unit Root. Econometrica, 64, 813-836. http://dx.doi.org/10.2307/2171846

Halicioglu, F. (2011). A Dynamic Econometric Study of Income, Energy and Export in Turkey. Energy Economics, 36, 3348-3354. http://dx.doi.org/10.1016/j.energy.2011.03.031

Hill, R. C., Griffith, W. E., \& Lim, G. C. (2008). Principles of Econometrics (3rd ed.). Wiley.

Hsiao, F. S. T., \& Hsioa, M. C. (2006). FDI, Export and GDP in East and Southeast Asia-Panel Data versus Time Series Causality Analysis. Journal of Asian Economics, 17, 1082-1106. http://dx.doi.org/10.1016/j.asieco.2006.09.011

Hussain, M., Javaid, M. I., \& Drake, P. R. (2012). An Econometric Study of Carbon Dioxide (CO2) Emissions, Energy Consumption, and Economic Growth of Pakistan. International Journal of Energy Sector Management, 6(4), 518-533. http://dx.doi.org/10.1108/17506221211282019

Indati, M., \& Bekhet, H. A. (2014). Highlighting of the Factors and Policies Affecting CO2 Emissions Level in Malaysian Transportation Sector. World Academy of Science, Engineering and Technology, International Science Index 85. International Journal of Environmental, Earth Science and Engineering, 8(1), 10-18.

Ivy-Yap, L., \& Bekhet, H. A. (2014). Modeling Residential Electricity Consumption Function in Malaysia: Time Series Approach. International Journal of Electrical, Electronic Science and Engineering, 8(3), 39-45.

Jumbe, C. B. L. (2004). Cointegration and causality between electricity consumption and GDP: Empirical evidence from Malawi. Energy Economics, 26, 61-68. http://dx.doi.org/10.1016/S0140-9883(03)00058-6

Kraft, J., \& Kraft, A. (1978). On The Relationship Between Energy and GNP. Journal of Energy and Development, 3, 401-403.

Kwiatkowski, D., Phillip, P., Schmidt, P., \& Shin, Y. (1992). Testing the Null Hypothesis of Stationary Against the alternative of a Unit Root: How Sure Are We That Economics Time Series have a Unit Root? Journal of Econometrics, 54, 159-178. http://dx.doi.org/10.1016/0304-4076(92)90104-Y

Lane, J. E. (2011). CO2 Emissions and GDP. International Journal of Social Economics, 38(11), 911-918. http://dx.doi.org/10.1108/03068291111171414

Lau, L. S., Choong, C. K., \& Eng, Y. K. (2014). Investigation of the Environmental Kuznets Curve for Carbon Emissions in Malaysia: Do Foreign Direct Investment and Trade Matter? Energy Policy, 68, 490-497. http://dx.doi.org/10.1016/j.enpol.2014.01.002

Lean, H. H., \& Smyth, R. (2010a). On the dynamics of aggregate output, electricity consumption and exports in Malaysia: Evidence from multivariate Granger causality tests. Applied Energy, 87, 1963-1971. http://dx.doi:10.1016/j.apenergy.2009.11.017

Lean, H. H., \& Smyth, R. (2010b). Multivariate Granger causality between electricity generation, exports, prices and GDP in Malaysia. Energy, 35, 3640-3648. http://dx.doi:10.1016/j.energy.2010.05.008

Lee, C. C., \& Chang, C. P. (2009). FDI, Financial Development and Economics Growth: International Evidence. Journal of Applied Economics, XII, 249-271. http://dx.doi.org/10.1016/S1514-0326(09)60015-5 
Malaysia Energy Commission. (2013). National Energy Balance. Putrajaya.

Montgomery, D. S., Jennings, C. L., \& Kulahci, M. (2008). Introduction to Time series Analysis and Forecasting (1st ed.). Canada: John Wiley and Sons.

Mozumder, P., \& Marathe, A. (2007). Causality relationship between electricity consumption and GDP in Bangladesh. Energy Policy, 35, 375-402. http://dx.doi.org/10.1016/j.enpol.2005.11.033

Narayan, P. K., \& Smyth, R. (2009). Multivariate Granger Causality Between Electricity Consumption, Exports and GDP: Evidence from a Panel of Middle Eastern Countries. Energy Policy, 37, 229-236. http://dx.doi:10.1016/j.enpol.2008.08.020

Ng, S., \& Perron, P. (2001). Lag Selection and the Construction of Unit Root Tests With Good Size and Power. Econometrica, 69, 1519-1554. http://dx.doi.org/10.1111/1468-0262.00256

Odhiambo, N. M. (2009). Electricity consumption and economic growth in South Africa: A trivariate causality test. Energy Economics, 31, 635-640. http://dx.doi.org/10.1016/j.eneco.2009.01.005

Owokuse, T. O. (2007). Causality between Exports, Import, and Economic Growth: Evidence from Transition Economies. Economics Letter, 94, 389-395. http://dx.doi.org/10.1016/j.econlet.2006.08.025

Pao, H. T., \& Tsai, C. M. (2011). Multivariate Ganger Causality between CO2 Emissions, Energy Consumption, FDI (Foreign Direct Investment) and GDP (Gross Domestic Product): Evidence from a Panel of BRIC (Brazil, Russian Federation, India, and China) Countries. Journal of Energy, 36, 685-693. http://dx.doi.org/10.1016/j.energy.2010.09.041

Pesaran, M. H., Shin, Y., \& Smith, R. (2001). Bound testing approaches to the analysis of level relationships. Journal of Applied Econometrics, 16, 289-326. http://dx.doi.org/10.1002/jae.616

Phillips, P. C. B., \& Perron, P. (1988). Testing for a Unit root in Time Series Regression. Biometrica, 75, 335346. http://dx.doi.org/10.1093/biomet/75.2.335

Saboori, B., Sulaiman, J., \& Mohd, S. (2012). Economic Growth and CO2 Emissions in Malaysia: A Co-Integration Analysis of The Environmental Kuznet Curve. Energy Policy, 51, 184-191. http://dx.doi.org/10.1016/j.enpol.2012.08.065

Sadorsky, P. (2011). Trade and Energy Consumption in the Middle East. Energy Economics, 33, 739-749. http://dx.doi.org/10.1016/j.eneco.2010.12.012

Sadorsky, P. (2012). Energy Consumption, Output and Trade in South America. Energy Economics, 34, 476-488. http://dx.doi.org/10.1016/j.eneco.2011.12.008

Sami, J. (2011). Multivariate Co-integration and Causality between Exports, Electricity Consumption and Real income per Capita: Recent Evidence from Japan. International Journal of Energy Economics and Policy, 3, $59-68$.

Sbia, R., Shahbaz, M., \& Hamdi, H. (2014). A Contribution of Foreign Direct Investment, Clean Energy, Trade Openness, Carbon Emissions and Economic Growth to Energy Demand in UAE. Economic Modelling, 36, 191-197. http://dx.doi.org/10.1016/j.econmod.2013.09.047

Shahbaz, M. (2012). Does Trade Openness Affect Long Run Growth? Co-integration, Causality and Forecast Error Variance Decomposition Test for Pakistan. Economic Modelling, 29, 2325-2339. http://dx.doi.org/10.1016/j.econmod.2012.07.015

Shahbaz, M., \& Lean, H. H. (2012). The Dynamics of Electricity Consumption and Economic Growth: A Revisit Study of Their Causality in Pakistan. Energy, 39, 146-153. http://dx.doi.org/10.1016/j.energy.2012.01.048

Shiu, A., \& Lam, P. L. (2004). Electricity consumption and economic growth in China. Energy Policy, 32, 47-54. http://dx.doi.org/10.1016/S0301-4215(02)00250-1

Tang, C. F. (2008a). Electricity consumption, income, foreign direct investment and population in Malaysia. Journal of Economics Studies, 36, 371-382. http://dx.doi.10.1108/01443580910973583

Tang, C. F. (2008b). A re-examination of the relationship between electricity consumption and economic growth in Malaysia. Energy Policy, 36, 3077-3085. http://dx.doi.org/10.1016/j.enpol.2008.04.026

Thornton, J. (1996). Co-integration, Causality and Export-Led Growth in Mexico, 1895-1992. Economics Letter, 50, 413-416. http://dx.doi.org/10.1016/0165-1765(95)00780-6

Westerlund, J. (2006). Testing for panel cointegration with multiple structural breaks. Oxford Bulletin of 
Economics and Statistics, 68, 101-132. http://dx.doi.org/10.1111/j.1468-0084.2006.00154.x

\section{Copyrights}

Copyright for this article is retained by the author(s), with first publication rights granted to the journal.

This is an open-access article distributed under the terms and conditions of the Creative Commons Attribution license (http://creativecommons.org/licenses/by/3.0/). 